\title{
Thermodynamic modeling and phase equilibrium calculations in nuclear materials
}

\author{
Arthur D. Pelton \\ Centre de Recherche en Calcul Thermochimique \\ Ecole Polytechnique de Montreal, P. O. Box 6079, Station " Downtown » \\ Montreal, Quebec, H3C 3A7, CANADA
}

Abstract: Thermodynamic systems of interest in nuclear engineering generally consist of many components and many phases. To perform thermodynamic calculations involving equilibria among solid, liquid and gaseous phases, large evaluated databases of the thermodynamic properties of compounds and multicomponent solutions are required, as well as software for performing the equilibrium computations. The development of general Gibbs energy minimization software is well advanced, and a number of software packages are available commercially. The development of thermodynamic databases for multicomponent systems proceeds by the critical evaluation of sub-systems in which all available thermodynamic and phase equilibrium data are optimized simultaneously to obtain one selfconsistent set of model equations for the Gibbs energies of all phases as functions of temperature and composition. The parameters of these equations are stored in the databases, and the models are used to estimate the properties of the multicomponent solutions. It is very important to choose a model which correctly reflects the structure of the solution. Examples of databases and of equilibrium calculations in nuclear materials applications are presented.

\section{INTRODUCTION}

In recent years, several thermodynamic database computing systems for inorganic applications have been developed. Three of the largest are $F * A * C * T$ (Montreal), Thermocalc (Stockholm) and MTDATA (Teddington, UK). These systems combine databases of the thermodynamic properties of several thousand pure substances and solutions with Gibbs energy minimization software for the calculation of multicomponent, multiphase equilibria.

Such database systems are useful in calculations in nuclear thermodynamics which typically involve large numbers of components and phases. For example, Fig. 1 shows the results of an equilibrium calculation (1) with the $F * A * C * T$ system to simulate a Loss-of-Coolant Accident involving a $\mathrm{UO}_{2}$ fuel. The equilibrium condition att $2000 \mathrm{~K}$ and $1.0 \mathrm{~atm}$ is calculated when $1014.5 \mathrm{~mol} \mathrm{UO}_{2}$ with the molar trace element composition shown react with $3725 \mathrm{~mol} \mathrm{H}_{2} \mathrm{O}$ and $3725 \mathrm{~mol} . \mathrm{H}_{2} . \quad\left(\mathrm{H}_{2} / \mathrm{H}_{2} \mathrm{O}=1.0, \mathrm{Cs} /\left(\mathrm{H}_{2} \mathrm{O}+\right.\right.$ $\left.\mathrm{H}_{2}\right)=10^{-4}$ ). At equilibrium, $7455.6 \mathrm{~mol}$ of gas of the calculated composition shown are at equilibrium with several condensed phases as shown. The calculations involved consideration of 174 gaseous species and 210 condensed phases for which data (sometimes estimated) are available in the $F * A * C * T$ databases. For brevity, Fig. 1 shows only those condensed phases which are calculated to occur at equilibrium, and only the major gaseous species containing each element.

In Fig. 1, only pure condensed phases are considered. The usefulness of database computing systems is greatly increased by the inclusion of databases for solid and liquid solutions. These solution databases contain the parameters of model equations giving the thermodynamic properties as functions of composition and temperature. These parameters are obtained by the critical evaluation and optimization of available data for binary and ternary solutions, and the models are then used to extrapolate to multicomponent solutions. 


$$
\begin{aligned}
& \text { 1014.5 } \mathrm{UO}_{2}+0.096 \mathrm{~Np}+2.754 \mathrm{Pu}+0.824 \mathrm{Ce}+0.215 \mathrm{Y}+0.138 \mathrm{Te}+0.332 \mathrm{La}+1.442 \mathrm{Zr}+ \\
& 0.389 \mathbf{B a}+0.899 \mathbf{R u}+1.150 \mathrm{Mo}+0.265 \mathbf{P r}+0.421 \mathbf{S r}+0.0385 \mathbf{I}_{2}+0.859 \mathrm{Nd}+0.043 \mathbf{~ N b}+ \\
& 0.0064 \mathrm{Am}+0.745 \mathrm{Cs}+0.166 \mathrm{Rh}+0.006 \mathrm{Sb}+0.025 \mathrm{Eu}+3725 \mathrm{H}_{2} \mathrm{O}+3725 \mathrm{H}_{2}=
\end{aligned}
$$

\begin{tabular}{|c|c|c|c|c|}
\hline $7455.6 \mathrm{~mol}$ & $\begin{array}{ll} & 0.50125 \\
+ & 0.49723 \\
+ & 0.11454 \mathrm{E}-02 \\
+ & 0.11584 \mathrm{E}-03 \\
+ & 0.73447 \mathrm{E}-04 \\
+ & 0.60706 \mathrm{E}-04 \\
+ & 0.36397 \mathrm{E}-04 \\
+ & 0.22365 \mathrm{E}-04 \\
+ & 0.22265 \mathrm{E}-04 \\
+ & 0.18304 \mathrm{E}-04 \\
+ & 0.49495 \mathrm{E}-05 \\
+ & 0.34483 \mathrm{E}-05 \\
+ & 0.32535 \mathrm{E}-05 \\
+ & 0.27916 \mathrm{E}-05 \\
+ & 0.24118 \mathrm{E}-05 \\
+ & 0.23163 \mathrm{E}-05 \\
+ & 0.21235 \mathrm{E}-05 \\
+ & 0.21085 \mathrm{E}-05 \\
+ & 0.18160 \mathrm{E}-05 \\
+ & 0.16420 \mathrm{E}-05 \\
+ & 0.12401 \mathrm{E}-05 \\
+ & 0.11913 \mathrm{E}-05 \\
+ & 0.95219 \mathrm{E}-06\end{array}$ & $\begin{array}{l}\mathrm{H} 2 \\
\mathrm{H} 2 \mathrm{O} \\
\mathrm{H} \\
\mathrm{OH} \\
\mathrm{CsOH} \\
\mathrm{O} 2 \mathrm{Mo}(\mathrm{OH}) 2 \\
\mathrm{Ba}(\mathrm{OH}) 2 \\
\mathrm{Cs} \\
\mathrm{RhO} 2 \\
\mathrm{Te} \\
\mathrm{I} \\
\mathrm{UO} 3 \\
\mathrm{CsI} \\
\mathrm{NdO} 2 \\
\mathrm{LaO} 2 \mathrm{H} 2 \\
\mathrm{MoO} 3 \\
\mathrm{HI} \\
\text { (EuO2H2) } \\
\mathrm{NbO} 2 \\
\mathrm{BaMoO4} \\
\text { (EuOH) } \\
\mathrm{BaOH} \\
\mathrm{BaO}\end{array}$ & $\begin{array}{l}\text { Solids and Liquids } \\
+1014: 1 \mathrm{~mol} \\
+2.7534 \mathrm{~mol} \\
+0.50174 \mathrm{~mol} \\
+0.42100 \mathrm{~mol} \\
+0.41908 \mathrm{~mol} \\
+0.29947 \mathrm{~mol} \\
+0.15695 \mathrm{~mol} \\
+0.13233 \mathrm{~mol} \\
+0.13208 \mathrm{~mol} \\
+0.10750 \mathrm{~mol} \\
+0.96000 \mathrm{E}-01 \mathrm{~mol} \\
+0.89372 \mathrm{E}-01 \mathrm{~mol} \\
+0.45776 \mathrm{E}-01 \mathrm{~mol} \\
+0.14062 \mathrm{E}-01 \mathrm{~mol} \\
+0.31987 \mathrm{E}-02 \mathrm{~mol}\end{array}$ & $\begin{array}{l}\mathrm{UO}_{2} \\
\mathrm{PuO}_{2} \\
\mathrm{Ru} \\
(\mathrm{SrUO} 4) \\
(\mathrm{Nd} 2 \mathrm{O} 3)(\mathrm{ZrO} 2) \\
\mathrm{ZrO} 2 \\
\mathrm{La}^{2} 3 \\
\mathrm{Mo5Ru} 3 \\
\mathrm{Pr} 2 \mathrm{O} 3 \\
(\mathrm{Y} 2 \mathrm{O} 3)(\mathrm{ZrO} 2) 2 \\
\mathrm{NpO} 2 \\
(\mathrm{BaO})(\mathrm{ZrO} 2) \\
\mathrm{Ce} 18 \mathrm{O} 31 \\
\mathrm{Nb} 2 \mathrm{O5} \\
\mathrm{Am} 2 \mathrm{O} 3\end{array}$ \\
\hline
\end{tabular}

Fig. 1.Calculated (1) Equilibrium conditions at $2000 \mathrm{~K}$ and $1.00 \mathrm{~atm}$ for reaction of $\mathrm{UO}_{2}$ containing trace elements with $\left(\mathrm{H}_{2} / \mathrm{H}_{2} \mathrm{O}\right)=1.0$ and $\mathrm{Cs} /\left(\mathrm{H}_{2} \mathrm{O}+\mathrm{H}_{2}\right)=10^{-4}$ in a Loss-of-Coolant Accident

The aim of the present article is to give a brief introduction to the current state of the art in the thermodynamic modeling of solutions, and to provide a few examples of applications of large evaluated solution databases to nuclear thermodynamics. The examples are taken from the $F * A * C * T$ system of which the author is a co-developer.

A more detailed discussion of the models can be found in references $(2,3)$.

\section{POLYNOMIAL MODELS}

In the simplest model, for a binary solution $\mathrm{A}-\mathrm{B}$, the molar Gibbs energy is given by :

$$
g=\left(X_{A} g_{A}^{o}+X_{B} g_{B}^{o}\right)+R T\left(X_{A} \ln X_{A}+X_{B} \ln X_{B}\right)+g^{E}
$$

where $g_{i}^{O}$ is the Gibbs energy of pure $i, X_{i}$ is the mole fraction of $i$, and $g^{E}$ is the excess Gibbs energy which can be expanded as :

$$
\left.g^{E}=\alpha X_{A} X_{B}=I^{0} L+{ }^{1} L\left(X_{B}-X_{A}\right)+{ }^{2} L\left(X_{B}-X_{A}\right)^{2}+\ldots\right] X_{A} X_{B}
$$

where the ${ }^{i} L$ are parameters which are, in general, functions of $T$. If only the first term, ${ }^{\circ} L$, is non-zero, then $\alpha=$ constant and the solution is " regular ".

A critical evaluation/optimization of a binary solution consists in determining the values of the parameters which best reproduce simultaneously all available data (activities, Gibbs energies, enthalpies of mixing, phase diagrams, etc.) Generally, the experimental phase diagram is the most useful source of data. Furthermore, since a major practical goal of developing the database is to permit the calculation of heterogeneous equilibria, it is most important to reproduce the phase diagram. As an example, the 
calculated Pu-U phase diagram $(4,5)$ is shown in Fig. 2 along with some experimental data points (6-8). Although data points are not shown in the lower part of the diagram, the fit is as good. The optimized parameters used to calculate the diagram are given in Table 1. These were obtained by least-squares optimization of the phase diagram data. Techniques of least squares optimization have been discussed ( 9 11). The values of $g_{i}^{o}$ for the stable phases of $P u$ and $U$ were taken from the $F * A * C * T$ pure substance database. Note that for a phase such as $\gamma-\mathrm{Pu}$, in which $\mathrm{U}$ is only sparingly soluble, $\gamma_{\mathrm{U}}^{\circ}$ becomes an adjustable model parameter. For the $\eta$ and $\zeta$ phases, both $g_{P_{w}}^{o}$ and $g_{U}^{o}$ are adjustable model parameters.

TABLE 1 Optimized Parameters (cal/mol) for the Pu-U system (4)

\begin{tabular}{|c|c|c|}
\hline $\begin{array}{c}\text { Liquid } \\
\varepsilon-\gamma(\Gamma) \\
\delta^{\prime}-P u \\
\delta-P u \\
\gamma-P u \\
\beta-P u \\
\beta-U \\
\alpha-U \\
\eta\end{array}$ & $\begin{array}{l}g^{E} \\
g^{E} \\
g_{U}^{0} \\
g_{U}^{i} \\
g_{U}^{0} \\
g_{U}^{0} \\
g_{P_{u}}^{0} \\
g_{P_{u}}^{:} \\
g_{P_{u}}^{\circ} \\
g_{U}^{0} \\
g^{E} \\
g_{P_{u}}^{0} \\
g_{U}^{0} \\
g^{z}\end{array}$ & $\begin{array}{l}=X_{p_{u}} X_{U}(80) \\
=X_{p_{u}} X_{U}\left(730-390 X_{U}\right) \\
=g_{U}^{0}(\beta)+(2204-0.4745 T) \\
=g_{U}^{0}(\beta)+(2228-0.4745 T) \\
=g_{U}^{0}(\gamma)+(953.5+0.8967 T) \\
=g_{U}^{0}(\gamma)+(205.3+1.1307 T) \\
=g_{P_{u}}^{0}(\varepsilon)+(491.3+0.0828 T) \\
=g_{P_{u}}^{\circ}(\varepsilon)+(-322.0+1.792 T) \\
=g_{P_{u}}^{0}(\varepsilon)+(-169+0.2714 T) \\
=g_{U}^{0}(\beta)+(128-0.0838 T) \\
=X_{p_{u}} X_{U}\left(-760.2+1.338 T-138.8 X_{U}\right) \\
=g_{P_{u}}^{0}(\varepsilon)+(-669+1.7914 T) \\
=-1742.7+31.9883 T+4.3500\left(10^{-4}\right) T^{2} \\
=-1.08633\left(10^{-6}\right) T^{3}-6.5470 T 1 n T+11450.0 T^{-1} \\
=X_{P_{u}} X_{U}\left(-1750+200 X_{U}\right)\end{array}$ \\
\hline
\end{tabular}

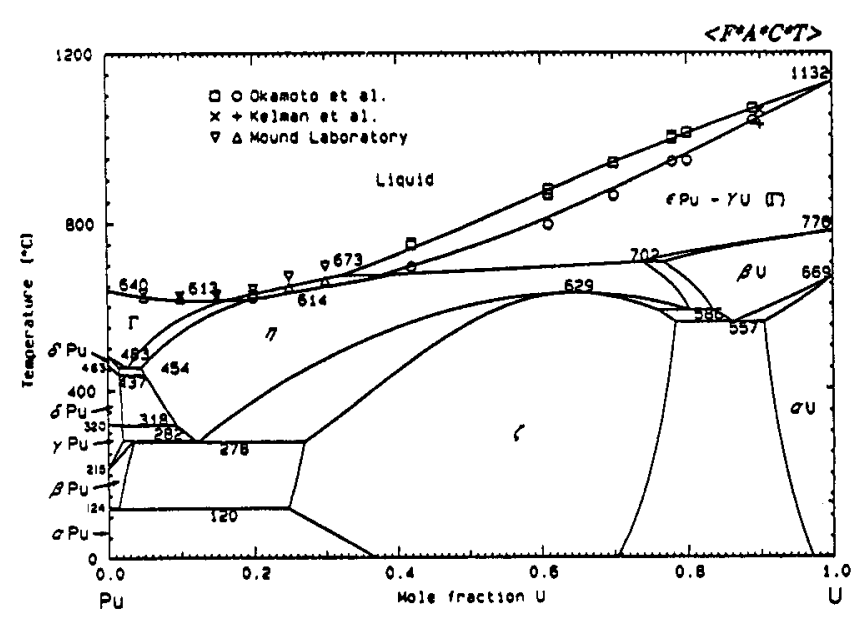

Fig. 2 Calculated optimized Pu-U phase diagram (4)

Similar optimizations of the U-Zr and Pu-Zr systems have been performed (12, 5). Each contains a $\Gamma$ solid solution phase of the same structure as the $\Gamma(\varepsilon-\gamma)$ phase in the Pu-U system. To the Gibbs energy of the ternary $\Gamma$ solution, we apply regular solution theory

$$
g=a_{A B} X_{A} X_{B}+a_{B C} X_{B} X_{C}+a_{C A} X_{C} X_{A}
$$

where $\mathrm{A}, \mathrm{B}, \mathrm{C}=\mathrm{U}, \mathrm{Pu}, \mathrm{Zr}$. However, we see in Table 1 that $\alpha_{P U U}$ is not constant but is equal to (730-390 $\left.X_{U}\right)$ in the Pu-U binary system. Similarly $\alpha_{P u z r}$ and $\alpha_{U z r}$ are not constant. For the ternary solution we follow the model of Kohler (13) that $\alpha_{i j}=$ constant along lines of constant $X_{i} / X_{j}$ ratio. (Other similar models are also used. See $(2,3)$.) We can now use the model to calculate the solvus surface of the $\Gamma$ phase in equilibrium with other lower-temperature solids in the ternary system. The resultant calculated solvus is a few degrees lower than the available experimental data, so we add a small adjustable ternary term of ( $3800 X_{P_{u}} X_{U} X_{2 r}$ ) to $\mathrm{Eq}(2)$ in order to give the calculated solvus in Fig. 3 (5) which agrees within experimental error limits with all available ternary data. This system is of interest in the Integral Fast Reactor (IFR) fuel. 
As another example, the liquidus of the Fe-U-Zr system, calculated (14) by the Kohler model from the optimized properties of the binary systems with no additional ternary terms is shown in Fig. 4. In these calculations it was assumed that solid $\mathrm{Fe}_{2} \mathrm{U}$ and $\mathrm{Fe}_{2} \mathrm{Zr}$ are immiscible. If, instead, an ideal solid solution of $\mathrm{Fe}_{2} \mathrm{U}$ and $\mathrm{Fe}_{2} \mathrm{Zr}$ is assumed, then the liquidus temperature is increased ,but only in this composition region. Most likely, $\mathrm{Fe}_{2} \mathrm{U}$ and $\mathrm{Fe}_{2} \mathrm{Zr}$ are partially miscible, and a few measurements of liquidus temperatures in this region will permit the $\mathrm{Fe}_{2} \mathrm{U}-\mathrm{Fe}_{2} \mathrm{Zr}$ solid solution to be modeled.

The binary and ternary parameters are stored in the solution databases. By the systematic optimization of many binary and ternary systems, large multicomponent databases are developed. Eq (2), along with the Kohler or similar models, is used to estimate the properties for a multicomponent solution from the stored parameters of its binary and ternary sub-systems. For example, reasonable calculations of phase equilibria in the quaternary Fe-U-Pu-Zr system can now be made. This system is of interest in fuel-cladding interactions in the IFR, as well as in major reactor accident scenarios.

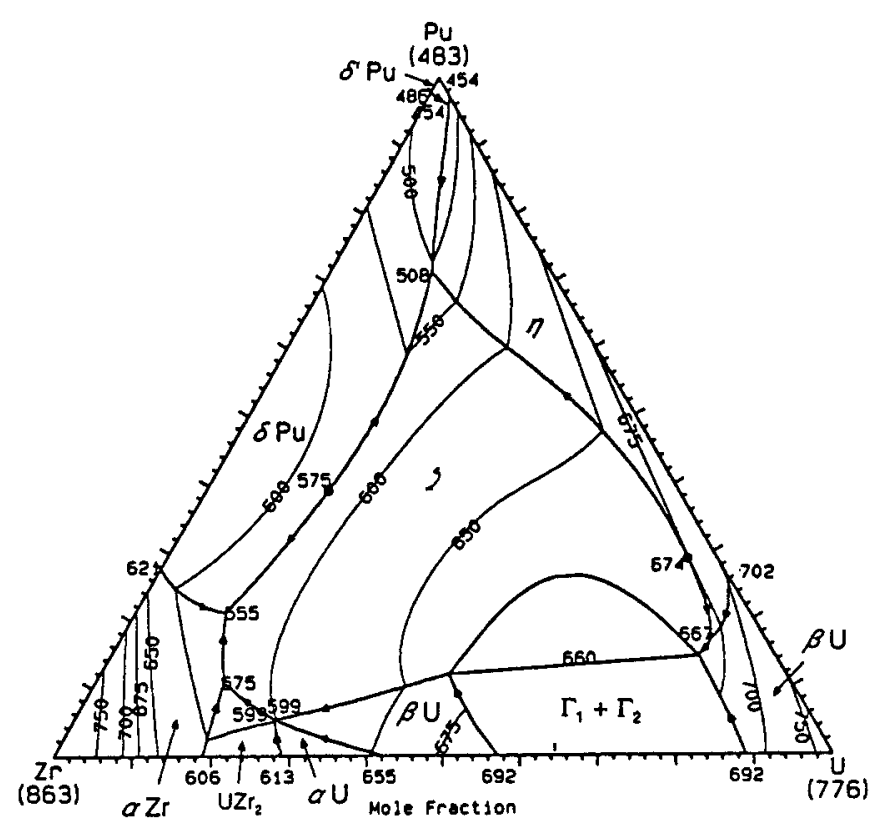

Fig. 3 Calculated projection of the solvus surface of the $\Gamma$ solid solution phase in the Pu-U-Zr system (5). ( $\mathrm{T}$ in ${ }^{\circ} \mathrm{C}$ )
As a final example, from optimizations of the binary systems $\mathrm{LiCl}-\mathrm{CeCl}_{3}, \quad \mathrm{CaCl}_{2}-\mathrm{CeCl}_{3}$ and $\mathrm{LiCl}-\mathrm{CaCl}_{2}$, the thermodynamic properties of ternary liquid $\mathrm{LiCl}-\mathrm{CaCl}_{2}-\mathrm{CeCl}_{3}$ solutions were estimated (15) (with no additional ternary terms). The calculated ternary eutectic point at $425^{\circ} \mathrm{C}$ at $48 \% \mathrm{CeCl}_{3}, 25 \% \mathrm{CaCl}_{2}$ and $27 \%$ $\mathrm{LiCl}$ (all weight \%) agrees well with the reported (16) values of $420^{\circ} \mathrm{C}$ at $47 \% \mathrm{CeCl}_{3}, 23 \% \mathrm{CaCl}_{2}$ and $3-\%$ $\mathrm{LiCl}$. Such molten salt systems involving rare earth chlorides with alkali or alkaline earth chlorides are of interest in the removal of rare earth impurities from $\mathrm{Pu}$.

Such simple polynomial models are based upon regular solution theory which assumes approximately random mixing. Experience has shown that good results are obtained for simple alloys and for

common-anion or common-cation molten salt solutions in which mixing interactions are relatively weak. For liquids with strong interactions, however, significant short-range ordering occurs, and more sophisticated models must be used.

\section{SHORT-RANGE ORDERING}

In the modified quasichemical model $(17-19,2,3)$, the exchange of nearest-neighbour pairs in a binary system is considered according to :

$$
(\mathrm{A}-\mathrm{A})+(\mathrm{B}-\mathrm{B})=2(\mathrm{~A}-\mathrm{B})
$$

The energy for this reaction is $(\omega-\eta T)$. If $(\omega-\eta T)$ is very negative, then (A - B) pairs are favoured. A « quasichemical » equilibrium constant can be written for reaction (3):

$$
K_{A B}=X_{A B}^{2} / X_{A A} X_{B B}=4 \exp [-(\omega-\eta T) / R T]
$$

where $X_{i j}$ is the fraction of total nearest-neighbour pairs which are $(\mathrm{i}-\mathrm{j})$ pairs. When $(\omega-\eta T)$ is very negative, the resultant expression for the Gibbs energy of the system goes through a sharp minimum 
at $X_{A}=X_{B}=0.5(2,3,17)$. In order to provide more flexibility in optimizing data, $(\omega-\eta T)$ can be expanded as :

$$
(\omega-\eta T)=\left(\omega_{o}-\eta_{O} T\right)+\left(\omega_{1}-\eta_{1} T\right) X_{B}+\left(\omega_{2}-\eta_{2} T\right) X_{B}^{2}+\ldots
$$

where $\omega_{i}$ and $\eta_{i}$ are the model parameters. If the minimum in the Gibbs energy is observed at a composition other than $\mathrm{X}_{\mathrm{A}}=\mathrm{X}_{\mathrm{B}}=0.5$, this can be accommodated in the model by an appropriate choice of the ratio of coordination numbers $Z_{B} / Z_{A}$. For example, if the minimum is near $X_{B}=1 / 3$, then $Z_{B} / Z_{A}=2$.

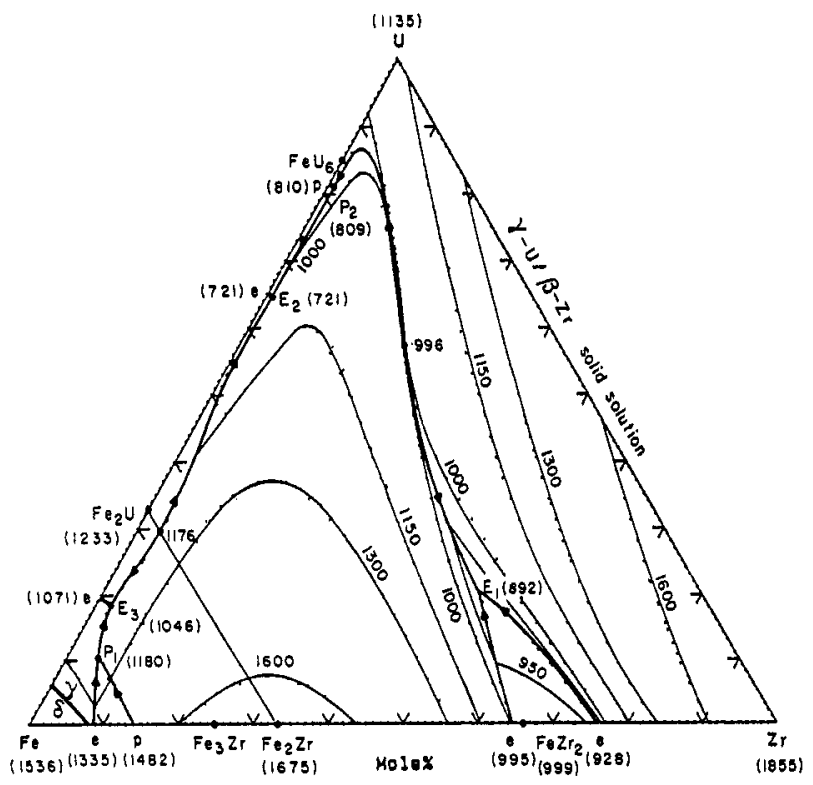

Fig. 4 Calculated (14) Fe-U-Zr liquidus surface assuming no solid solution between $\mathrm{Fe}_{2} \mathrm{Zr}$ and $\mathrm{Fe}_{2} \mathrm{U}\left(\mathrm{T}\right.$ in $\left.{ }^{\circ} \mathrm{C}\right)$
The quasichemical model for short-range ordering has been applied with success to ordered liquid alloys and to molten metal sulphide solutions. Much success has also been achieved for silicate melts and glasses. In a binary silicate, $\mathrm{AO}_{\mathrm{x}}-\mathrm{SiO}_{2}(\mathrm{~A}=\mathrm{Ca}$, $\mathrm{Mg}, \mathrm{Na}, \ldots$ ), the tendency to short-range ordering can be identified with the tendency to form $\mathrm{SiO}_{4}^{4-}$ ions in basic solutions, or with the break-up of the silicate network in acid solutions, and the resultant formation of second-nearest-neighbour (A-Si) pairs. An (Si-Si) pair can be considered to be joined by a doubly-bonded (network) oxygen, an (A-A) pair is a pair of cations separated by an $\mathrm{O}^{2-}$ ion, and an (A-Si) pair represents an oxygen bonded to one $\mathrm{Si}$. Hence, the quasichemical reaction (3) is applied for second-nearest-neighbour pairs. This is related to the well-known equilibrium among free, singly-bonded and doubly-bonded oxygen:

$$
\mathrm{O}^{2-}+\mathrm{O}^{0}=2 \mathrm{O}^{\circ}
$$

and is also closely related to " cell » models of silicate melts (20).

As example, the calculated optimized (21) phase diagram of the $\mathrm{CaO}-\mathrm{SiO}_{2}$ system is shown in Fig. 5 . Only 6 parameters were required in $\mathrm{Eq}(5)$ to reproduce, within error limits, the measured phase diagram, and all other thermodynamic data such as activities in the liquid.

Once several binary systems have been optimized in this way, the quasichemical model can be used to predict the thermodynamic properties of multicomponent slags and glasses by assuming that the values of $K_{i j}$ in $\mathrm{Eq}(4)$ for the multicomponent solution are equal to their values in the binary systems at the same values of $X_{i} / X_{j}$ or $X_{\mathrm{SiO}_{2}}$. (For details, see ref. (22).) The phase diagram of the $\mathrm{CaO}-\mathrm{Al}_{2} \mathrm{O}_{3}-\mathrm{SiO}_{2}$ system, calculated (22) in this way, with the addition of two additional small ternary parameters, is shown in Fig. 6. Agreement with measured liquidus temperatures, as well as with liquid activity measurements, is within error limits.

The quasichemical model has been applied systematically to the optimization of a large number of oxide systems to develop the $F * A * C * T$ slag/glass databases for the oxides of $A l, B, C a, C r(I I), C r(I I I)$, $\mathrm{Fe}(\mathrm{II}), \mathrm{Fe}(\mathrm{III}), \mathrm{Mg} \mathrm{Mn}, \mathrm{Na}, \mathrm{Pb}, \mathrm{Si}, \mathrm{Ti}(\mathrm{III}), \mathrm{Ti}(\mathrm{IV}), \mathrm{Zn}, \mathrm{Zr}$. At the same time, optimized databases have been developed for solid oxide solutions (spinels, ilmenites, olivines, perovskites, etc.).

This database has been used to calculate equilibrium crystallization (liquidus) temperatures for 15 -component $\left(\mathrm{Na}_{2} \mathrm{O}_{3}-\mathrm{B}_{2} \mathrm{O}_{3}-\mathrm{SiO}_{2}-\mathrm{Li}_{2} \mathrm{O}-\mathrm{CaO}-\mathrm{MgO}-\mathrm{FeO}-\mathrm{Fe}_{2} \mathrm{O}_{3}-\mathrm{Al}_{2} \mathrm{O}_{3}-\mathrm{ZrOCrO}-\mathrm{Cr}_{2} \mathrm{O}_{3}-\mathrm{MnO}-\mathrm{NiO}-\mathrm{TiO}_{2}\right)$ 
sodium borosilicate glasses of interest in nuclear waste vitrification. A comparison of predicted liquidus temperatures with measurements (23) on 80 glasses of various compositions is given in Fig. 7 (24). Depending on the composition, the calculated primary crystalline phases include zirconia, zircon, silica, anorthite, hematite, olivine, llithium silicate, lithium aluminum silicate, sodium zirconium silicate, $\mathrm{Na}_{2} \mathrm{Ca}_{3} \mathrm{Si}_{6} \mathrm{O}_{16}$, albite and $\mathrm{Mg}_{2} \mathrm{BO}_{3}$ as well as clinopyroxene $\left(\mathrm{NaFeSi}_{2} \mathrm{O}_{6}-\mathrm{CaMgSi}_{2} \mathrm{O}_{6}\right)$, corundum $\left(\mathrm{Cr}_{2} \mathrm{O}_{3}-\mathrm{Fe}_{2} \mathrm{O}_{3}-\mathrm{Al}_{2} \mathrm{O}_{3}\right)$ and $\left(\mathrm{Na}_{2} \mathrm{Ca}_{2} \mathrm{Si}_{3} \mathrm{O}_{9}-\mathrm{Na}_{4} \mathrm{CaSi}_{3} \mathrm{O}_{9}\right)$ solid solutions. The average deviation in Fig. 7 is $32^{\circ}$.

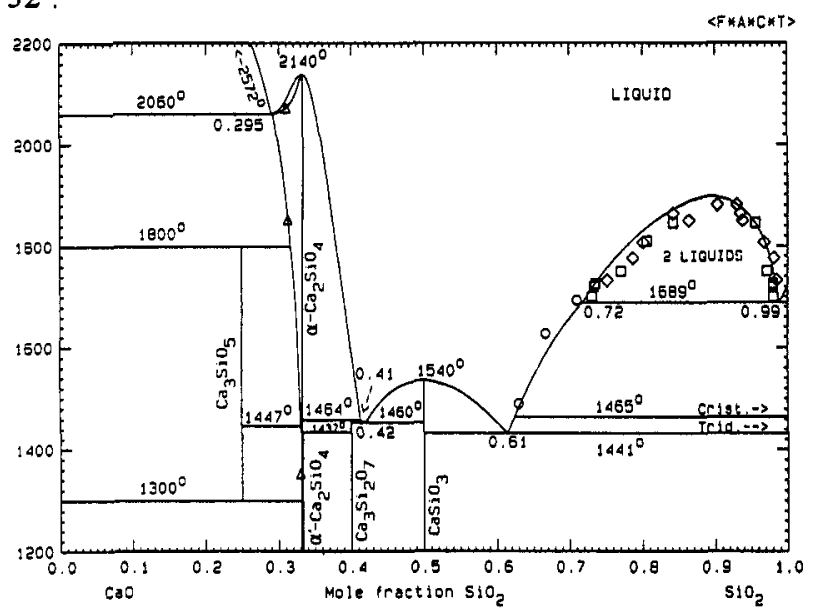

For liquid $\mathrm{ReCl}_{3}-\mathrm{ACl}$ solutions where $\mathrm{Re}=$ rare earth and $\mathrm{A}$ is a large alkali cation $(\mathrm{K}, \mathrm{Rb}, \mathrm{Cs})$, the Gibbs energy curves pass through relatively sharp minima near $X_{\mathrm{ReCl}_{3}}=0.25 \quad\left(\mathrm{~A}_{3} \mathrm{ReCl}_{6}\right)$, indicating short-range ordering about this composition. The modified quasichemical model can be used for these solutions, with $Z_{\mathrm{Re}} / Z_{\mathrm{A}}=3$.

Fig. 5 Calculated (21) optimized $\mathrm{CaO}-\mathrm{SiO}_{2}$ phase diagram and comparison with selected experimental points

\section{SOLUTION OF $\mathrm{SO}_{3}, \mathrm{PO}_{4}, \mathrm{~S}$ AND HALIDES IN SLAGS/GLASSES}

Reddy and Blander (25) proposed a simple model, later modified by Pelton et al (26), which has proven successful in predicting the solubility of $\mathrm{S}^{2-}$ ions in oxide slags/glasses. It is assumed that $\mathrm{S}^{2-}$ ions substitute nearly ideally for $\mathrm{O}^{2-}$ ions and for $\mathrm{SiO}_{4}$ groups in the solution. The model can be very simply adapted to permit the calculation of the solubility of other anions $\left(\mathrm{SO}_{4}^{2-}, \mathrm{Cl}^{-}, \mathrm{r}, \mathrm{PO}_{4}^{3-}, \mathrm{OH}\right)$ by assuming ideal substitution for $\mathrm{O}^{2-}$ ions and $\mathrm{SiO}_{4}$ groups. For example, under oxidizing conditions sulphur dissolution as sulphate can be written:

$$
\mathrm{O}^{2-}+\mathrm{SO}_{3}=\mathrm{SO}_{4}^{2-}
$$

Sulphate solubilities at a given $\mathrm{SO}_{3}$ partial pressure can thus be predicted from a knowledge only of $\mathrm{g}^{0}$ of the pure sulphates $\left(\mathrm{Na}_{2} \mathrm{SO}_{4}, \mathrm{CaSO}_{4}\right.$, etc.) and of the activities of the oxides $\left(\mathrm{Na}_{2} \mathrm{O}, \mathrm{CaO}\right.$, etc. $)$ in the solution (which are given by the quasichemical model database) with no adjustable parameters. Calculated (24) solubilities for $\mathrm{SiO}_{2}-\mathrm{CaO}-\mathrm{Na}_{2} \mathrm{O}-\left(\mathrm{Al}_{2} \mathrm{O}_{3}-\mathrm{MgO}\right)$ glasses are compared with experimental values (27) in Table 2. Similarly good agreement has been found (24) with measurements of sulphate solubilities of other authors for many other glass compositions. Quite good agreement for the solubility of phosphate and chloride in oxide glasses was also obtained (24). Fluoride and iodide solubilities could also be reproduced (24)) although in these cases a Henrian activity coefficient had to be introduced as an adjustable parameter.

The solubilities of sulphate, phosphate and halides in glasses are important in the vitrification of nuclear wastes, since separate undesirable salt phases will form if the solubility limits are exceeded. The model outlined here can also be extended to the dissolution of $\mathrm{H}_{2} \mathrm{O}$ in oxide slags/glasses.

\section{SUBLATTICE MODELS}

The sublattice concept was first developed extensively for molten salt solutions (28). The cations are assumed to form a solution on a cationic sublattice, while the anions form a separate solution on an 
anionic sublattice. Interactions between ions on the same sublattice are modeled by the excess terms in the common-ion systems (e.g. $\mathrm{LiCl}-\mathrm{NaCl}, \mathrm{NaCl}-\mathrm{NaF}$ ), while interactions between ions on different

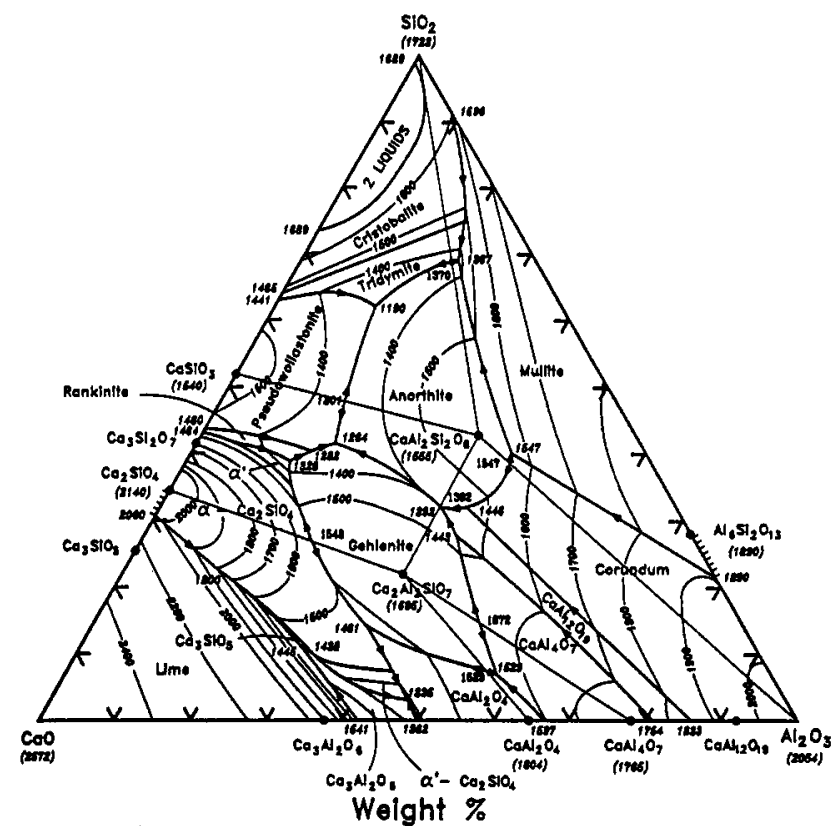

Fig. 6 Calculated (22) optimized $\mathrm{CaO}-\mathrm{Al}_{2} \mathrm{O}_{3}-\mathrm{SiO}_{2}$ liquidus surface $\left(\mathrm{T}\right.$ in $\left.{ }^{\circ} \mathrm{C}\right)$ sublattices are modeled through the Gibbs energy of exchange reactions, such as :

$$
\begin{gathered}
\mathrm{LiCl}+\mathrm{NaF}=\mathrm{NaCl}+\mathrm{LiF} \\
\Delta G=g_{N o C l}^{o}+g_{\text {LiF }}^{o}-g_{\text {NaF }}^{o}-g_{\text {LiCl }}^{o}
\end{gathered}
$$

For a description of the model for molten salts, see (29). The model has been used to develop an optimized $\mathrm{F} * \mathrm{~A} * \mathrm{C} * \mathrm{~T}$ database for $\mathrm{Li}, \mathrm{Na}, \mathrm{K}, \mathrm{Rb}, \mathrm{Cs}, \mathrm{Mg}$, $\mathrm{Ca} / \mathrm{F}, \mathrm{Cl}, \mathrm{Br}, \mathrm{I}, \mathrm{OH}, \mathrm{NO}_{3}, \mathrm{CO}_{3}, \mathrm{SO}_{4}$ and other molten salt solutions as well as for the associated solid solution phases.

The sublattice concept has also proven very successful in modeling the thermodynamics of ceramic phases such as spinels in which the tetrahedral sites constitute one sublattice and the octahedral sites another. Through use of the very useful "Compound Energy

Formalism » (30-32), the same mathematical formalism can be used for these solutions as is used for salt solutions. The sublattice model and the Compound Energy Formalism have also been applied, mainly by the Thermocalc group, to the development of extensive databases for interstitial solutions and for intermetallic phases.

\section{DISCUSSION}

For the successful development of a thermodynamic database for a multicomponent solution, the choice of a model which correctly reflects the structure of the solution is essential. Models are now well developed to treat solutions of alloys, molten salts, oxide slags/glasses, ceramic phases, etc. Furthermore, Gibbs energy minimization software exists to perform equilibrium calculations in multiphase, multicomponent solutions using data from these databases. In order to render the present thermodynamic database computing systems more useful in nuclear thermodynamics, future developments should focus upon the inclusion of more components by critical evaluation and optimization of data. For example, to model the molten oxide phase resulting during a meltdown accident by reaction of the core with concrete, it will be necessary to add $\mathrm{UO}_{2}$ as well as many other oxides as components to the slag database.

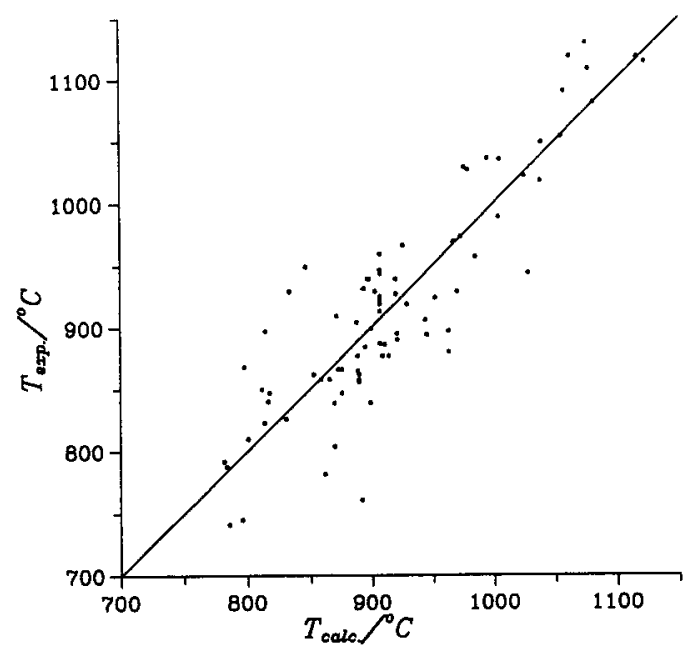

Fig. 7 Calculated (24) versus experimental (23) crystallization (liquidus) temperatures for 15-component nuclear waste disposal glasses. 


\section{REFERENCES}

1. W.T. Thompson, M.H. Kaye, B.J. Lewis, B. Corse, F.C. Iglesias, B. André, Royal Military College, Kingston, Ontario, private communication (1996).

2. A.D. Pelton, Ch. 1 in Materials Science and Technology, vol. 5 (R.W. Cahn, P. Haasen and E. J. Krainer ed.), pp 1-75, VCH, NY (1991).

3. A.D. Pelton, Ch. 3 in Advanced Physical Chemistry in Process Metallurgy (N-Sano, W.-K. Lu, P.V. Riboud and M. Maeda ed.) Academic, NY, in press.

4. L. Leibowitz, R.A. Blomquist and A.D. Pelton, J. Nucl. Mater, 167, 76-81 (1989).

5. P.K. Talley, A.D. Pelton and L. Leibowitz, to be submitted to J. Nucl. Mater.

6. F. H. Ellinger, R.O. Elliott and E.M. Cramer, J. Nucl. Mater, 3, 233, (1959).

7. L.R. Kelman, H. Savage, C.M. Walter, B. Blumenthal, R.J. Dunworth and H.V. Rhude, in Plutonium 1965, (A.E. Kay and M.B. Wadron ed.) pp. 458-484, Chapman and Hall, London (1967).

8. Mound Laboratory Report MLM-1402, Miamisburg, Ohio (1967).

9. H.L. Lukas, E.-Th. Henig and B. Zimmermann, Calphad, 1, 225-236 (1977).

10. P. Dörner, E.-Th. Henig, H. Krieg, H.L. Lukas and G. Petzow, Calphad, 4, 241-254 (1980).

11. C.W. Bale and A.D. Pelton, Metall. Trans., 14B, 77-84 (1983).

12. L. Leibowitz, R.A. Blomquist and A.D. Pelton, J. Nucl. Mater., 184, 59-64 (1991).

13. F. Kohler, Monatsh. Chem., 91, 738 (1960).

14. A.D. Pelton, P.K. Talley, L. Leibowitz and R.A. Blonquist, J. Nucl. Mat., 210, 324-332 (1994).

15. P. Chartrand, M.Sc. thesis, Ecole Polytechnique, Montreal (1995).

16. C. Liang, C. Zheng and Y. Ye, J. Chinese Rare Earth Soc., 8, 76 (1990)

17. A.D. Pelton and M. Blander, Proc. AIME Sympos. Molten Salts and Slags, pp. 281-294, Am. Inst. Met. Eng., Warrendale, PA (1984).

18. A.D. Pelton and M. Blander, Metall. Trans., 17B, 806-815 (1986).

19. M. Blander and A.D. Pelton, Geochim. Cosmochim. Acta, 51, 85-95 (1987).

20. M.L. Kapoor and M.G. Frohberg, Sympos. Chem. Metall. Iron and Steel, Sheffield, England (1971).

21. G. Eriksson, P. Wu, M. Blander and A.D. Pelton, Canad. Metall. Quart., 33, 13-22 (1994).

22. G. Eriksson and A.D. Pelton, Metall. Trans., 24B, 807-816 (1993).

23. P. Hrma, D.-S. Kim, J. Vienna, Battelle-PNL, Richland WA, private communication (1994).

24. A.D. Pelton, P. Wu. G. Eriksson and S. Degtiarev. Final Report, Contract No. 157998-A, to Battelle-PNL, Richland Wa (1995).

25. R.B. Reddy and M. Blander, Metall. Trans., 18B, 591 (1987).

26. A.D. Pelton, G. Eriksson and A. Romero-Serrano, Metall. Trans., 24B, 817-825 (1993).

27. K. Papadopoulos, Phys. Chem. Glasses, 14, 60-65 (1973).

28. M. Blander, ch. 3 in Molten Salt Chemistry (M. Blander, ed.), Interscience, NY (1964).

29. A.D. Pelton, Calphad, 12, 127-142 (1988).

30. B. Sundman and J.Ågren, J. Phys. Chem. Solids, 42, 297 (1981).

31. M. Hillert, B. Jansson and B. Sundman, Z. Metallk., 79, 81 (1988).

32. T. I. Barry, A.T. Dinsdale, J.A. Gisby, B. Hallstedt, M. Hillert, B. Jansson, J. Jonsson, B. Sundman and J.R. Taylor, J. Phase Equil., 13, 459-476 (1992).

Table 2

Calculated $\mathrm{SO}_{3}$ Solubllities in $\mathrm{SiO}_{2}-\mathrm{CaO}-\mathrm{Na}_{2} \mathrm{O}-\left(\mathrm{Al}_{2} \mathrm{O}_{3}-\mathrm{MgO}\right)$ Glasses at $P_{\mathrm{SO}_{3}}=0.01$ atm Compared to Measurements of Papadopoulos (27)

\begin{tabular}{|c|c|c|c|c|c|c|c|}
\hline \multirow{2}{*}{$\mathrm{T}\left({ }^{\circ} \mathrm{C}\right)$} & \multicolumn{5}{|c|}{ Mole fractions } & \multicolumn{2}{|c|}{$\mathrm{SO}_{3}$ (mole fraction) } \\
\hline & $\mathrm{SiO}_{2}$ & $\mathrm{Al}_{2} \mathrm{O}_{3}$ & $\mathrm{CaO}$ & Mgo & $\mathrm{Na}_{2} \mathrm{O}$ & $\begin{array}{c}\text { expt. } \\
\text { (corrected) }\end{array}$ & calc. \\
\hline 1370 & $\begin{array}{l}0.721 \\
0.722 \\
0.741 \\
0.707 \\
0.715 \\
0.653 \\
0.657 \\
0.685 \\
0.778 \\
0.778\end{array}$ & $\begin{array}{l}0.002 \\
0.001 \\
0.001 \\
0.001 \\
0.001 \\
0.002 \\
0.002 \\
0.002 \\
0.001 \\
0.001\end{array}$ & $\begin{array}{l}0.136 \\
0.142 \\
0.089 \\
0.200 \\
0.193 \\
0.196 \\
0.194 \\
0.144 \\
0.090 \\
0.144\end{array}$ & $\begin{array}{l}0.006 \\
0.004 \\
0.003 \\
0.005 \\
0.005 \\
0.005 \\
0.005 \\
0.004 \\
0.004 \\
0.004\end{array}$ & $\begin{array}{l}0.127 \\
0.123 \\
0.169 \\
0.083 \\
0.083 \\
0.133 \\
0.131 \\
0.164 \\
0.123 \\
0.071\end{array}$ & $\begin{array}{l}0.00746 \\
0.00636 \\
0.00864 \\
0.00280 \\
0.00280 \\
0.01216 \\
0.01050 \\
0.01066 \\
0.00360 \\
0.00133\end{array}$ & $\begin{array}{r}0.00716 \\
0.00685 \\
0.0103 \\
0.00417 \\
0.00385 \\
0.0162 \\
0.0161 \\
0.0156 \\
0.0044 \\
0.00186\end{array}$ \\
\hline $\begin{array}{l}1373 \\
1397 \\
1403 \\
1427 \\
1433 \\
1451 \\
1453 \\
1483\end{array}$ & $\begin{array}{l}0.653 \\
0.660 \\
0.659 \\
0.677 \\
0.669 \\
0.660 \\
0.665 \\
0.666\end{array}$ & $\begin{array}{l}0.002 \\
0.002 \\
0.002 \\
0.002 \\
0.002 \\
0.002 \\
0.002 \\
0.002\end{array}$ & $\begin{array}{l}0.196 \\
0.198 \\
0.194 \\
0.187 \\
0.192 \\
0.201 \\
0.194 \\
0.199\end{array}$ & $\begin{array}{l}0.004 \\
0.005 \\
0.004 \\
0.005 \\
0.004 \\
0.005 \\
0.006 \\
0.006\end{array}$ & $\begin{array}{l}0.132 \\
0.128 \\
0.131 \\
0.123 \\
0.128 \\
0.128 \\
0.129 \\
0.126\end{array}$ & $\begin{array}{l}0.0126 \\
0.0116 \\
0.0107 \\
0.0066 \\
0.0062 \\
0.0063 \\
0.0050 \\
0.0038\end{array}$ & $\begin{array}{l}0.0157 \\
0.0108 \\
0.0108 \\
0.0060 \\
0.0069 \\
0.0063 \\
0.0058 \\
0.0040\end{array}$ \\
\hline
\end{tabular}

